\title{
Analysis of Factors Influencing Agricultural Productivity in the Philippines
}

\author{
Jackie D. Urrutia*, Joseph Mercado, Katherine Eve E. Ebue, Faila \\ S. Raymundo and Bernadeth G. Nobles \\ Polytechnic University of the Philippines Sta. Mesa, Manila, Philippines; jdurrutia@pup.edu.ph, \\ jackieurrutia20@gmail.com, katheverine@gmail.com, math_urrutia@yahoo.com.ph, \\ mercado@pup.edu.ph, bgnobles_pupcs@yahoo.com, failaraymundo05@gmail.com
}

\begin{abstract}
Objectives: This paper aims to identify the factors influencing agricultural productivity which is measured by the real gross value added in agriculture and provide suggestion. Specifically, how Agricultural Land Area, Employment in Agriculture, Government Expenditure on Agriculture, Agriculture Raw Material Export, and Electric Consumption per Capita affects Real Gross Value Added. Taking account, the agricultural production function of the three basic factors of production land, labor and capital together with the raw material export and electric consumption. Methods/Statistical Analysis: The Philippine Agriculture is at risk causing poverty and employment, as reported year 2013, compared to how it boosts the economy decades ago. Through multiple regression analysis, the relationship between factors Agricultural Land Area, Employment in Agriculture, Government Expenditure on Agriculture, Agriculture Raw Material Export, and Electric Consumption per Capita and Real Gross Value Added has been established. Pearson Correlation test was used to check to what is the relationship between the Agricultural Gross Value Added and the independent variables. Since the data available for land area is in percent of the total land area, the data for Agricultural Land Area were converted into square kilometres to attain best result. The data always went through Test of Individual Significance, Granger-Causality Test and Paired-T Test. Findings: The dependent variables Agricultural Land Area, Employment, Government Expenditure on Agriculture, Agriculture Raw Material Export, Electric Consumption per Capita have p-values of 0.0008, 0.0014, 0.0042, 0.0000, and 0.0002 , respectively. Hence, the individual factors stated were found to contribute significantly to the Agriculture Real Gross Value Added. The correlation of coefficient of Agricultural Land Area, Employment, Government Expenditure on Agriculture, and Electric Consumption per Capita show a strong positive correlation to Real Gross Value Added, whilst, the correlation coefficient of Agricultural Raw Material Export implies a strong negative correlation. In line with the existing values about production, an additional unit for inputs would create an additional output. The conversion of agriculture lands into industrial and commercial space, and the likes, greatly affect in the decrease of agricultural production. The more agriculture raw materials Philippines would export, obviously, the lesser production. But, what if Philippines lack the ability to turn those raw materials into a new product? And, it is better to export it to generate an income. Then, it would be great if Philippines will also invest in agriculture raw materials processing. Application/Improvements: Real Gross Value Added contributes to Gross Domestic Product, which is a measurement of how well an economy of a certain country is. In other words, it affects the economy as a whole. Today's Philippine administration has been promoting boost in agriculture. In line with this paper's findings, the government pours sufficient financial support in Agriculture sector to address its needs. This paper will be more useful if it the data available would be up-to-date, since, data availability depends on the scheduling of census and funds as well.
\end{abstract}

Keywords: Agriculture Gross Value Added, Agriculture Production, Macroeconomics, Multiple Linear Regression, Philippine Agriculture, Time Series 


\section{Introduction}

Most of the developing countries got its biggest share on the Gross Domestic Product (GDP) from the agriculture sector. Knowing that the Philippines is both an agricultural and a developing country, its entire agriculture sector accounts for about 10 percent of total GDP according to the Bureau of Agricultural Statistics as of 2013. As of 2013, the current state of Philippine agriculture is at risk causing poverty and unemployment. Approximately 60 percent of the total population relies on income and employment from agriculture with a very low productivity that results to a low income among farmers. From 1990-2004 the agriculture shares to GDP went down to less than 15 percent from 21 percent in the previous decades. And in 2013, it continued to a downward trend to 10 percent. The Philippine annual growth rate in agriculture (value added) has been marked at 2.5 percent, from 1992-2003. Over the period of 2011 and 2013, agriculture Gross Value Added (GVA) average annual rate increased at 2.05 percent $^{1}$.

Many factors can affect the agricultural productivity which may include the land, labor and capital. Several decades ago, the country's economy and employment have been dependent on agriculture. Thirty-two percent of the Filipino workforce was engaged in agricultural-related in 2013. As the population is arithmetically increasing, the land suited for agriculture has declined; water availability became scarce, too. On the other hand, the capital that includes technologies, seeds, fertilizers and other investments that are useful for the production in agriculture declined also. The production of an output in agriculture may increase depending on the inputs that are available which leads to additional gross value added. GVA is an indicator of the gross domestic product. Compared to 1970s and early 1990s, many Filipinos are still inclined to agricultural activities but it's percent share to GDP declines, due to many factors. This paper sought to know the factors that affect the agricultural productivity, specifically how Agricultural Land Area, Employment, Government Expenditure on Agriculture, Agriculture Raw Material Export, and Electric Consumption per Capita may affect agriculture gross value added.

\section{Method}

E-views and SPSS were used to come up with more accurate and reliable results. For this study to be useful, the researchers conducted different statistical tests to know the significant influence of the independent variables such as Agricultural Land Area, Employment, Government Expenditure on Agriculture, Agriculture Raw Material Export, Electric Consumption per Capita, and Agriculture Gross Value Added.

Since the data for agricultural land area are available in percent of the total land area, the researchers converted it into square kilometers. The researchers looked for the total land area of the Philippines and came up with the following formula to convert the given data into square kilometer:

$$
\frac{A L A \%}{100} \times T L A
$$

Where:

ALA \% = agricultural land area in percent of total land area

TLA $=$ Total land area of the Philippines

To study if there is a relationship between the Agricultural Gross Value Added and the independent variables, the Pearson Correlation Test was used:

$$
r=\frac{n\left(\sum x y\right)-\left(\sum x\right)\left(\sum y\right)}{\sqrt{\left[n \sum x^{2}-\left(\sum x\right)^{2}\right]\left[n \sum y^{2}-\left(\sum y\right)^{2}\right]}}
$$

The value for $r$ with range from -1 to $1 .-1$ would indicate a perfect inverse correlation between the variables. The value of 0 indicates no relationship between the variables and a value of 1 means a perfect correlation between the variables ${ }^{2}$.

To establish the relationship between the Agricultural Gross Value Added and the different factors that affects it, the researchers used multiple linear regressions through matrices.

For simple linear regression, meaning one predictor, the model is:

$$
\hat{y}=\beta o+\beta_{1} x_{1}+\beta_{2} x_{2}+\beta_{3} x_{3}+\ldots .+\beta_{n} x_{n}+e_{i}
$$

\section{Where:}

$$
\begin{aligned}
& \hat{y}=\text { dependent variable } \\
& x_{i}=\text { independent variable, } \mathrm{i}=1,2,3,4,5 \ldots \mathrm{n} \\
& \beta_{0}=\text { Constant } \\
& \beta_{i}=\text { Regression Coefficient, } \mathrm{i}=1,2,3,4,5 \\
& e_{i}=\text { Stochastic Disturbance Term }
\end{aligned}
$$


This requires building up our symbols into vectors. Thus, $Y_{n \times 1}=\left(\begin{array}{c}Y_{1} \\ Y_{2} \\ Y_{3} \\ \vdots \\ Y_{n}\end{array}\right)$

captures the entire dependent variable in a single symbol. The " $n \times 1$ " part of the notation is just a shape reminder. These get dropped once the context is clear.

For simple linear regression, we will capture the independent variable through this $\mathrm{n} \times 2$ matrix:

$$
X_{n \times 2}=\left(\begin{array}{cc}
1 & x_{1} \\
1 & x_{2} \\
1 & x_{3} \\
\vdots & \vdots \\
1 & x_{n}
\end{array}\right)
$$

The coefficient vector will be $\beta_{2 \times 1}=\left(\begin{array}{c}\beta_{0} \\ \beta_{1}\end{array}\right)$ and the noise vector will be $\varepsilon_{n \times 1}=\left(\begin{array}{c}\varepsilon_{1} \\ \varepsilon_{2} \\ \varepsilon_{3} \\ \vdots \\ \varepsilon_{n}\end{array}\right)$.

The simple linear regression model is written then as $Y_{n \times 1}=X_{n \times 2} \beta_{2 \times 1}+\varepsilon_{n \times 1}$.

In the multiple regression case, we have

$$
X_{n \times p}=\left(\begin{array}{ccccc}
1 & x_{11} & x_{12} & \cdots & x_{1 K} \\
1 & x_{21} & x_{22} & \cdots & x_{2 K} \\
1 & x_{31} & x_{32} & \cdots & x_{3 K} \\
1 & x_{41} & x_{42} & \cdots & x_{4 K} \\
1 & x_{51} & x_{52} & \cdots & x_{5 K} \\
1 & x_{61} & x_{62} & \cdots & x_{7 K} \\
\vdots & \vdots & \vdots & \ddots & \vdots \\
1 & x_{n 1} & x_{n 2} & \cdots & x_{n K}
\end{array}\right) \text { and } \beta_{p \times 1}=\left(\begin{array}{c}
\beta_{0} \\
\beta_{1} \\
\beta_{2} \\
\beta_{3} \\
\vdots \\
\beta_{K}
\end{array}\right)
$$

The detail shown here is to suggest that is a tall, skinny matrix. We formally require In most applications, is much, much larger than .

The multiple regression model is now $X_{n \times p} \beta_{p \times 1}+\varepsilon_{n \times 1}$, and this is shorthand for

$$
\left(\begin{array}{c}
Y_{1} \\
Y_{2} \\
Y_{3} \\
\vdots \\
Y_{n}
\end{array}\right)=\left(\begin{array}{c}
\beta_{0}+\beta_{1} x_{11}+\beta_{2} x_{12}+\beta_{3} x_{13}+\ldots+\beta_{K} x_{1 K}+\varepsilon_{1} \\
\beta_{0}+\beta_{1} x_{21}+\beta_{2} x_{22}+\beta_{3} x_{23}+\ldots+\beta_{K} x_{2 K}+\varepsilon_{2} \\
\beta_{0}+\beta_{1} x_{31}+\beta_{2} x_{32}+\beta_{3} x_{33}+\ldots+\beta_{K} x_{3 K}+\varepsilon_{3} \\
\vdots \\
\beta_{0}+\beta_{1} x_{n 1}+\beta_{2} x_{n 2}+\beta_{3} x_{n 3}+\ldots+\beta_{K} x_{n K}+\varepsilon_{n}
\end{array}\right)
$$

The model form $Y=X \beta+\varepsilon$ is thus completely general ${ }^{3}$.

The researchers used Chow-Breakpoint test to know the structural or parameter stability of regression model and to test whether the external factors affect the parameter. It is not right to reject the null hypothesis of parameter stability if the computed F-value does not exceed the F-critical value at the chosen level of significance. ${ }^{2}$

$$
F=\frac{\left(R S S_{R}-R S S_{U R} / k\right.}{R S S_{U R} /\left(n_{1}+n_{2}-2 k\right)} F_{\left[k,\left(n_{1}+n_{2}-2 k\right)\right]}
$$

Correlation does not necessarily imply causation in any meaningful sense of that word. The researcher made use of Granger Causality to investigate causality between two variables in this time series analysis, thus, determine whether time series is useful for forecasting.

The Granger 1969 approach to the question of whether causes is to see how much of the current can be explained by the past values of and then to see whether adding lagged values of can improve the explanation. is said to be Granger-caused by if helps in the prediction of, or equivalently if the coefficient in the lagged 's are statistically significant.

$$
\begin{aligned}
& y_{t}=\alpha_{0}+\alpha_{1} y_{t-1}+\ldots+\alpha_{1} y_{t-1}+\beta_{1} x_{t-1}+\ldots+\beta_{l} x_{-l}+\varepsilon_{t} \\
& x_{t}=\alpha_{0}+\alpha_{1} x_{t-1}+\ldots+\alpha_{1} x_{t-1}+\beta_{1} y_{t-1}+\ldots+\beta_{l} y_{-l}+u_{t}
\end{aligned}
$$

The reported F-Statistics are the Wald statistics for the joint hypothesis:

$$
\beta_{1}=\beta_{2}=\ldots=\beta_{l}=0
$$

for each equation. The null hypothesis is that $x$ does not Granger-cause $y$ in the first regression that $y$ does not Granger-cause $x$ in the second regression ${ }^{4}$.

The Paired-Samples T Test procedure compares the means of two variables for a single group. The procedure 
computes the differences between values of the two variables for each case and tests whether the average differs from 0 . Observations for each pair should be made under the same conditions. The mean differences should be normally distributed. Variances of each variable can be equal or unequal. Paired T test is based on differences between the values of each pair, which is one subtracted from the other. It shows the ratio of the sum of the differences of each pair to the square root of $n$ times the sum of the differences squared minus the sum of the squared differences, all over $n-1{ }^{5}$.

$$
t=\frac{\sum d}{\sqrt{\frac{n\left(\sum d^{2}\right)-\left(\sum d\right)^{2}}{n-1}}}
$$

\section{Results and Discussions}

\subsection{Trend and Behavior of the Variables}

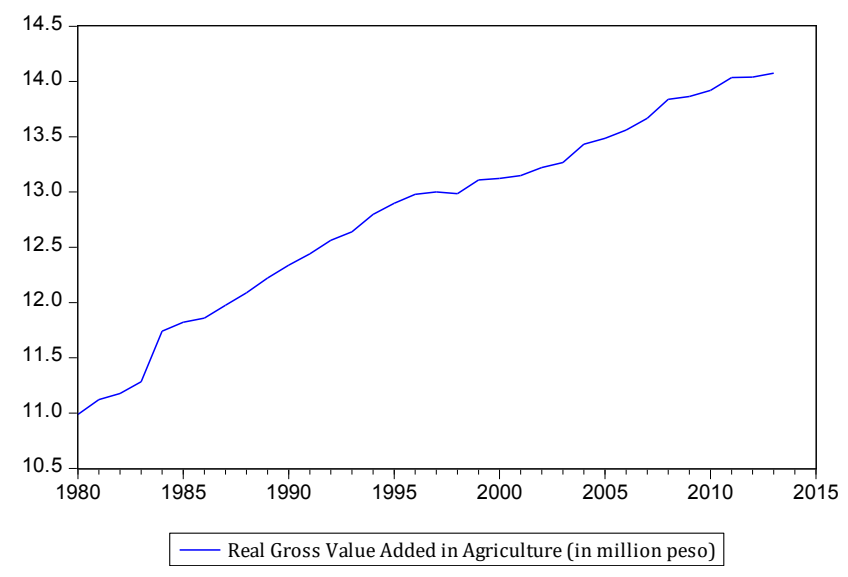

Figure 1. Real gross value added.

Graph shows the actual value of Agriculture Real Gross Value Added from 1980 to 2013. Over the 34-year period, there were minimal fluctuations in the growth of agriculture gross value added. The years 1980 to 1982 showed a little growth and started decline from year 1983 to 1985. Recovery took place from 1986 to 1997, then dropped again in 1998 and recovered in 1999 - the biggest growth in the trend, up to 2008. After these years, it started to decline in 2009 to 2011 - the utmost weakening, and making progress in 2012 and 2013. The trend is upward sloping with an average growth of 0.012 percent in the 34-year period.
After a slight increase from 1981 to 1982, GVA started to decline from 1983 to 1985 . This was the year of Martial Law, wherein the country faced so many economic problems. Marcos' imposed crony capitalism and economic cartels in the coconut and sugar industries. The money that was supposed to be used for fertilizer and to be lent to small farmers, was instead lent to Marcos' friends to set up business. Recovery took place during Aquino's administration through restoring market-oriented economy and abolished cartels and crony capitalism by breaking up the fertilizer cartel and bidding out fertilizer grants to private sectors. In 1997 and 1998, the Philippines was affected by Asian Financial Crisis. The economy was hit by currency devaluation causing business to shut down and a decline in importation whilst a negative growth in 1998 was due to severe drought. But, the Real Gross Value Added recovered in 1999. This was due to the gradual recovery of agricultural production from the devastation caused by El Niño.

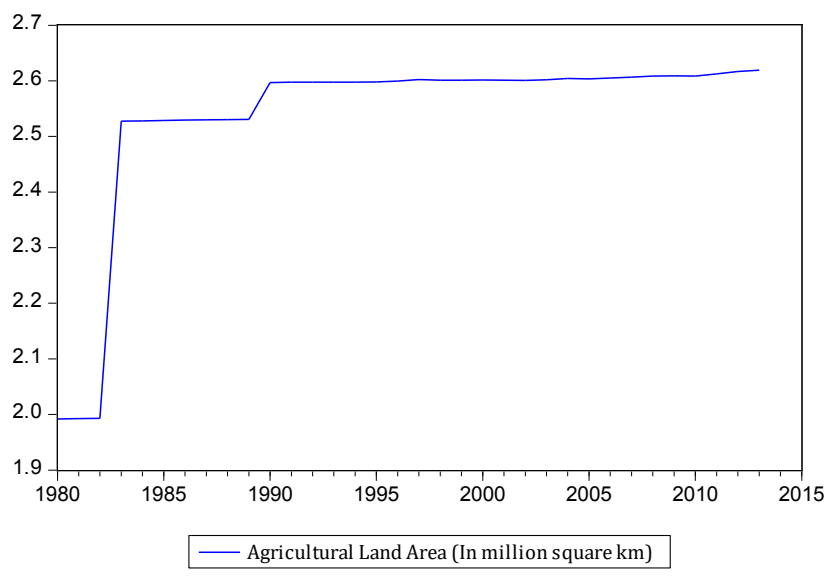

Figure 2. Agricultural land area.

Figure 3 shows the agricultural land area in the Philippines from 1980 to 2013 In three decades of observation in agricultural land, there are few declines during each decade. The largest decline in annual growth was in 1998 and 2005 followed by 2002 and 2010. There is more positive growth shown in agricultural land during 1981 to 1987 this was the largest growth. And the growth in every year is almost consistent.

In the late 1980s, nearly 8 million hectares--over 25 percent of total land--were under cultivation, 4.5 million hectares in field crops, and 3.2 million hectares in tree crops. Growth in agricultural output had to come largely from multi-cropping and increasing yields. In 1982 the Agricultural Land Area increases that much because the 
total territorial water area increased from 1.6 million hectares to 2.2 million hectares. In 1988 double-cropping and intercropping resulted in 13.4 million hectares of harvested area, a total that was considerably greater than the area under cultivation.

Over a period of ten years ending in 1996, the proportion of small farms had been expanding. The Philippine Agrarian Reform Council Secretariat reported that the government had acquired and distributed about 4.1 million hectares of agricultural lands to agrarian reform beneficiaries. Under this Program implementing the comprehensive agrarian reform law, a farm household cannot own a farm larger than five hectares. And so, in 1998, the agricultural land area declined by 0.09 . In 2000s there shown minimal fluctuations on agricultural land area; continues drop is seen in the year 2001 and 2002 by 0.02 percent in each year and then in 2003 and 2004 it rose up again by an average of 0.07 percent. In 2005 it decreased by 0.04 percent. Starting in 2006 the growth has become almost consistent except in 2010 which decreased by 0.02 percent; declination in agricultural area throughout this period was caused by typhoons, floods, and droughts.

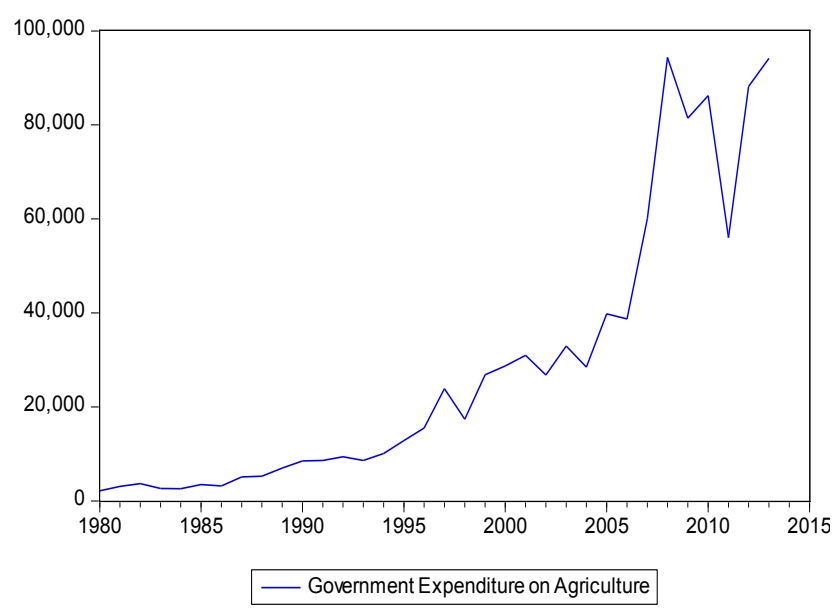

Figure 3. Government expenditure on agriculture.

The graph above shows the actual value of government expenditure in Philippine agriculture from 1980 to 2013. The growth has been increasing throughout the 34 years. Some declines are noticed in 1983, 1984, 1986, 1993 and 1998. Several drop are also visible in the years 2002, 2004, 2006 and 2009. The largest decline in government expenditure in agriculture was in 2011, while the largest growth was in 1987.

During Marcos' administration government financed its spending from foreign debt. In 1983, there were a high price of oil and slowdown in economic activities. The government was forced to borrow from International Monetary Fund. Furthermore, it was ordered by Marcos to cut the government spending and finance livelihood programs. There happened to be the so-called "flight of capital" and Philippines is heavily in debt during 1986. The government also employed measures to reduce overall government expenditures to reduce deficits. There was a sudden drop in government expenditure in 1998 which was due to Asian Financial Crisis. From 1999 to 2001, Estrada focused on agriculture. He implemented Executive Order 151, Farmer's Trust Fund, which allowed the voluntary consolidation of small farm operation into medium and large scale integrated enterprise that can access long-term capital. Also, he launched the Magkabalikat Para sa Kaunlarang Agraryo or MAGKASAKA and Agrikulturang Maka Masa. Futhermore, in 1999, a huge fund was allocated to Agricultural Programs. During 2002 to 2011, the government spending has been in debt payments, wages and salaries of employee, and subsidies to local government units. This mean that the budget become so lopsided. In 2011, a big drop in the growth rate of government expenditure was visible. The allocation of fund for agriculture ranked $5^{\text {th }}$. The government reduced the allocation for inputs subsidies such as seeds, fertilizer, farm implements, and biologics for the production of crops, livestock. And, in 2012 and 2013 Aquino allotted much greater fund for agriculture compared to the previous administration.

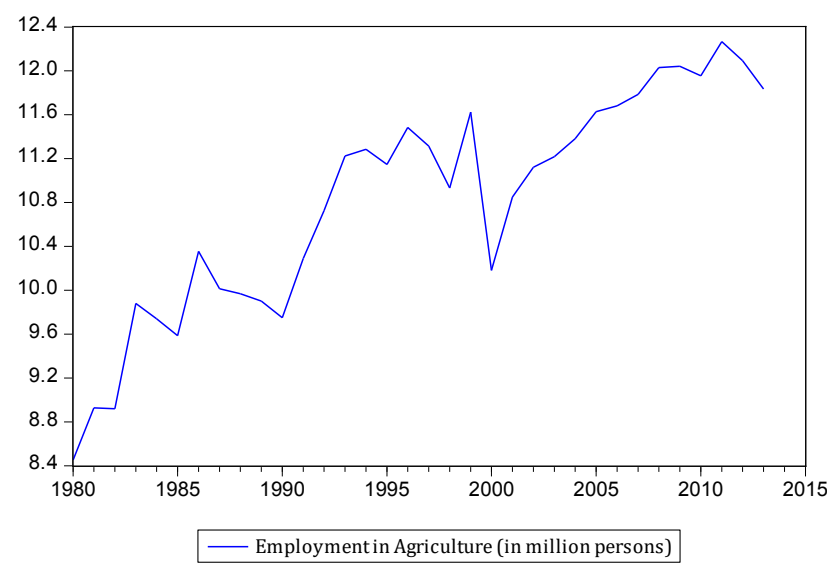

Figure 4. Employment on agriculture.

Figure 5, shows the employment on agriculture in the Philippines from 1980 to 2013. Simple annual growth is used. In three decades of observation in employment on agriculture, there are several declines during each decade. 
The largest decline in annual growth was in 1999 to 2000 followed by 1983 to 1985 . But there was positive growth shown by employment during 1991 to 1994; this was the largest growth followed by the growth of 2001 to 2008 .

The 1982, Martial Law takes place despite government efforts to pump-prime the economy to increase income and encourage spending unemployment and underemployment grew. And in 1988, unemployment rate of 8.3 percent (12.3 percent in urban areas) peaked at 11.4 percent in early 1989, and the underemployment rate, particularly acute for poor, less-educated, and elderly people, was approximately twice that of unemployment. About 470,000 Filipinos left the country to work abroad in contract jobs or as merchant seamen and resulted for 3.28 percent declines in employment. The decline in 1997 and 1998 annual growth in employment in Agriculture was caused by Asian Financial Crisis. GDP growth fell to about -0.6 percent in 1998 from 5.2 percent in 1997, but recovered to 3.4 percent by 1999 . It also resulted to the shutdown of some businesses, a decline in importation, a rising unemployment rate and an unstable financial sector. In 1998 decrease in employment on agriculture was caused by serious drought of lands that caused the unemployment of farmers. And since 2001 to 2009 employment on agriculture growth became stable in increasing with an average annual growth rate of 1.9 percent; the trend becomes upwardly sloping, 2010 to 2013 experienced high unemployment rate except in 2011 which increased by 2.6 percent.

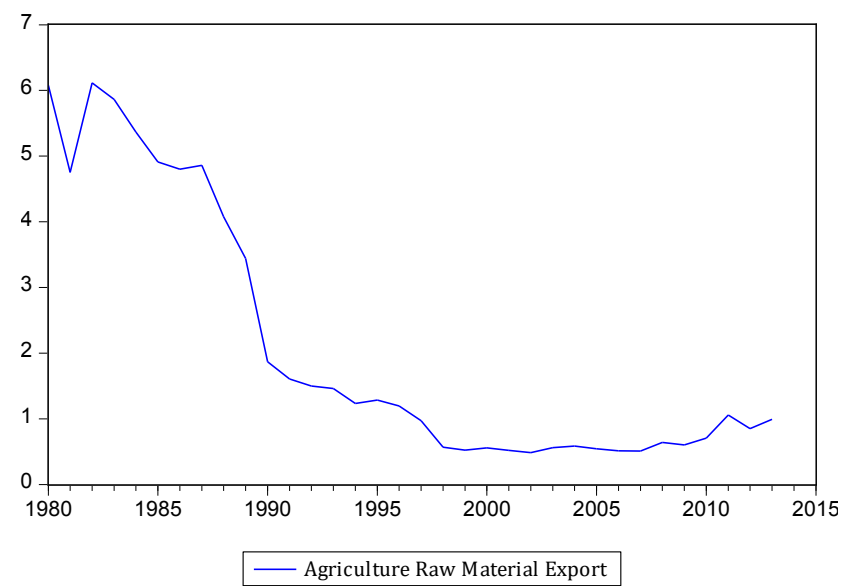

Figure 5. Agriculture raw material export.

Graph shows the Agriculture Raw Material Export in the Philippines from 1980 to 2013. In three decades of observation in Agriculture Raw Material Export, fluctuation is seen. A big decline is seen in year 1980-1981 but in year 1982 Philippines again increases its Agricultural Raw Material Export. However, after the export increase in 1982, a continuous decline is seen in later years. The largest decline was in 1988 to 1999. The graph formed a downhill line which indicates that Agricultural Raw Material Export decreases as years go on.

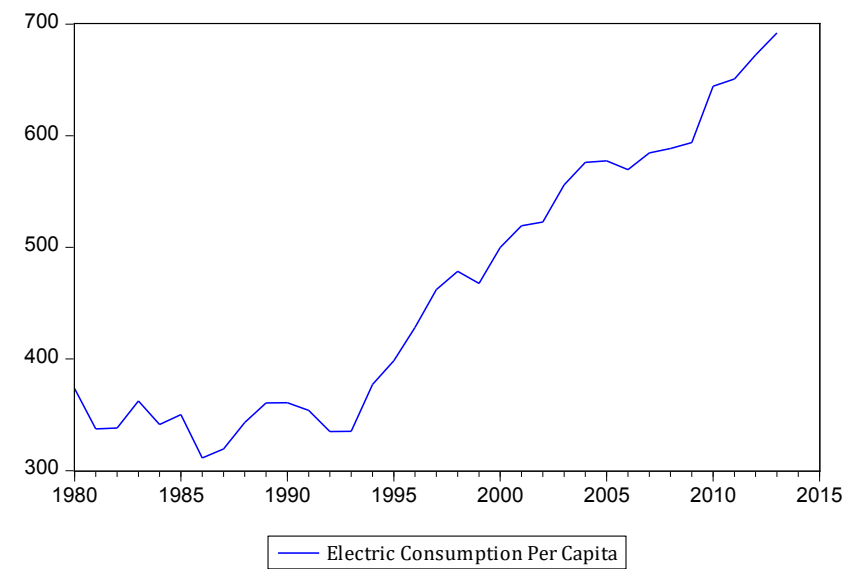

Figure 6. Electric consumption per capita.

Graph shows the Electric Consumption per Capita in the Philippines in 1980 to 2013. In three decades of observation in Electric Consumption per Capita, fluctuation is seen. A big decline can be seen in year 1984-1985 but in year 1986 Philippines again increases its Electric Consumption per Capita. However, after a continuous increase in 1986-1989 the Electric Consumption per Capita again dropped until 1993, and gradually increases in later years. As the graph shows, over the past 34 years this indicator reached a maximum value of 692.06 in 2013 and a minimum value of 341.32 in 1984 . The graph formed an uphill line which indicates that the Electric Consumption per Capita increases as the years go on.

\subsection{Test of Individual Significance Result}

Table 1. Test of significance result

\begin{tabular}{|l|l|l|l|l|}
\hline Var & $\mathbf{R}$ & $\mathbf{p}$ & Decision Rule & $\begin{array}{l}\text { Verbal } \\
\text { Interpretation }\end{array}$ \\
\hline $\mathrm{X}_{1}$ & 0.941 & 0.0008 & Reject $\mathrm{H}_{0}$ & Significant \\
\hline $\mathrm{X}_{2}$ & 0.702 & 0.0042 & Reject $\mathrm{H}_{0}$ & Significant \\
\hline $\mathrm{X}_{3}$ & 0.832 & 0.0014 & Reject $\mathrm{H}_{0}$ & Significant \\
\hline $\mathrm{X}_{4}$ & -0.900 & 0.0000 & Reject $\mathrm{H}_{0}$ & Significant \\
\hline $\mathrm{X}_{5}$ & 0.886 & 0.0002 & Reject $\mathrm{H}_{0}$ & Significant \\
\hline
\end{tabular}


The dependent variables Agricultural Land Area, Employment, Government Expenditure on Agriculture, Agriculture Raw Material Export, Electric Consumption per Capita have p-values of 0.0008, 0.0014, 0.0042, 0.0000, and 0.0002 , respectively. Since, p-values of each variables is less than the level of significance 0.01 we reject the null that there is no significant relationship between each variables and the dependent variable Agriculture Real Gross Value Added. Therefore, Agricultural Land Area, Employment, Government Expenditure on Agriculture, Agriculture Raw Material Export, Electric Consumption per Capita are significantly related to Agriculture Real Gross Value Added.

The Pearson Correlation that is used to identify the relationship of Real Gross Value Added and the independent variables states that the Agricultural Land Area, Employment, Government Expenditure on Agriculture, Agriculture Raw Material Export, Electric Consumption per Capita have correlation coefficients of 0.702, 0.941, $0.832,-0.900$, and 0.886 , respectively, with a p-value of 0.00 which is less than the 1 percent level of significance. The correlation of coefficient of Agricultural Land Area, Employment, Government Expenditure on Agriculture, and Electric Consumption per Capita show a strong positive correlation to Real Gross Value Added. It shows that 70.2 percent of the variation in Real Gross Value Added is explained by Agricultural Land Area, 94.1 percent for Employment, 83.2 percent for Government expenditure, and 88.6 percent for Electric consumption per capita. On the other hand, the correlation coefficient of Agricultural Raw Material Export implies a strong negative correlation with Real Gross Value Added. It shows that 90 percent of the variation in Real Gross Value Added is explained by Agricultural Raw Material Export.

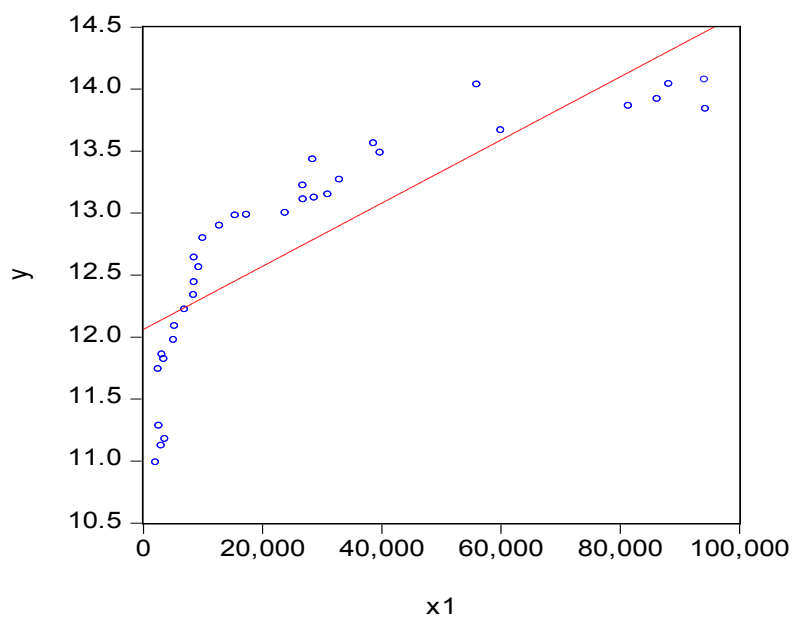

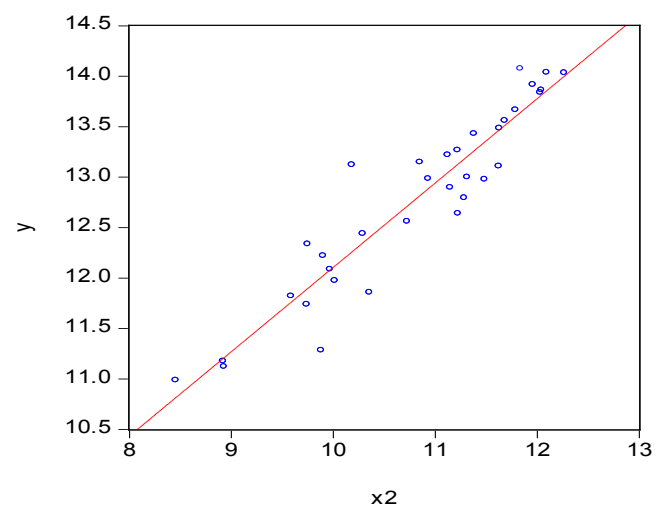
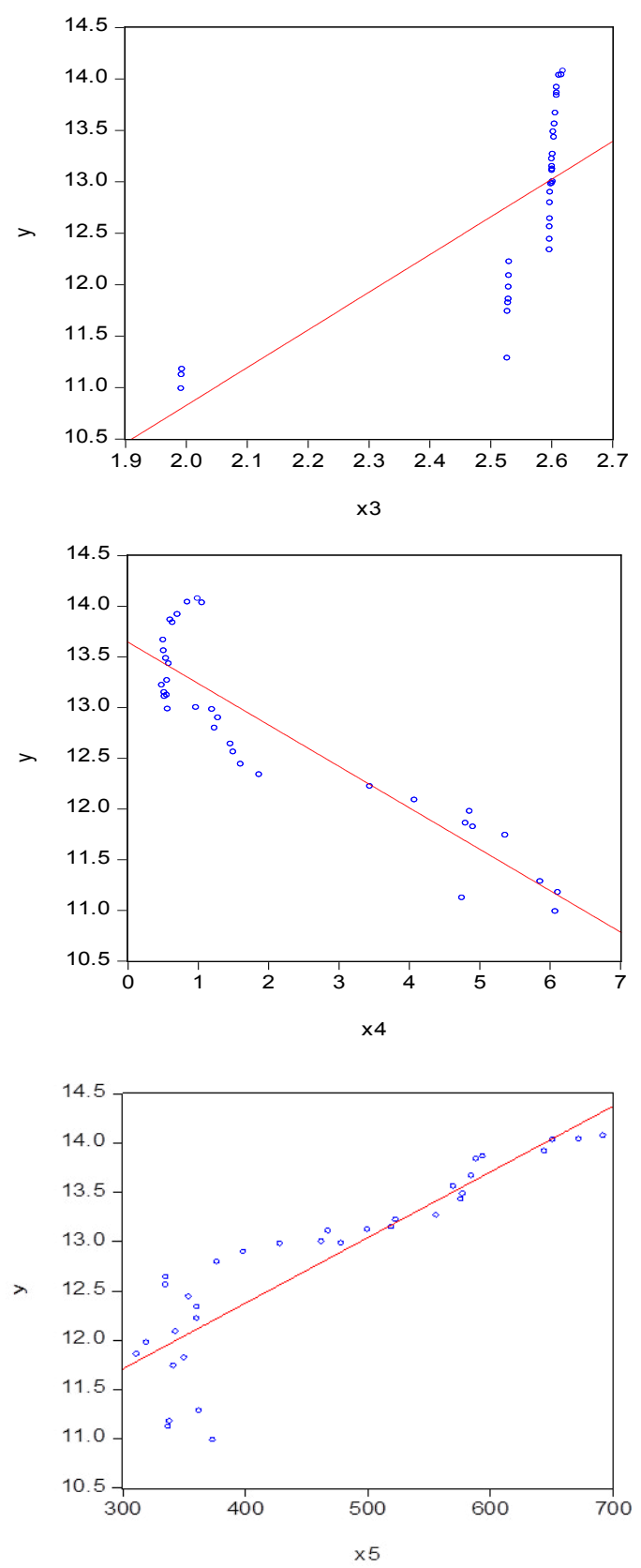

Figure 7. Scatterplots. 


\subsection{Regression Matrix and the Mathematical} Model

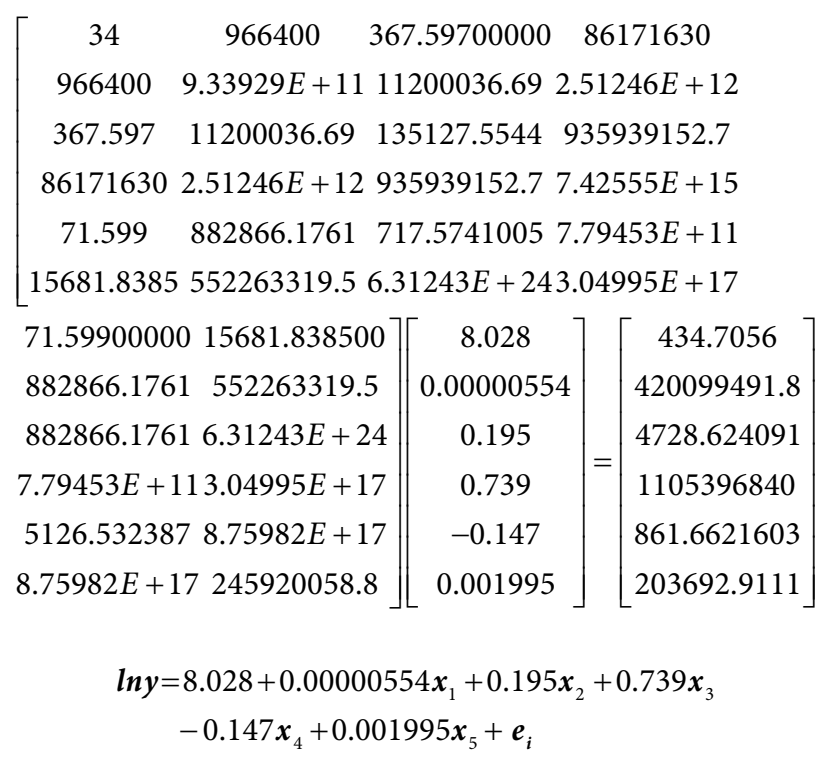

Where:

lny $=$ Agricultural Gross Value Added

$x_{1}=$ Government Expenditure

$x_{2}=$ Employment

$x_{3}=$ Agricultural Land Area

$x_{4}=$ agriculture raw material export

$x_{5}=$ electric consumption per capita

$\beta_{0}=$ Constant

$\beta_{i}=$ Regression Coefficient, $\mathrm{i}=1,2,3,4,5$

$e_{\mathrm{i}}=$ Stochastic Disturbance Term

Table 2. Regression result

\begin{tabular}{|l|l|l|l|l|}
\hline Var & p-value & Parameter & $\begin{array}{l}\text { Decision } \\
\text { Rule }\end{array}$ & $\begin{array}{l}\text { Verbal } \\
\text { Interpretation }\end{array}$ \\
\hline $\mathrm{X}_{1}$ & 0.0008 & 0.00000554 & Reject $\mathrm{H}_{0}$ & Significant \\
\hline $\mathrm{X}_{2}$ & 0.0042 & 0.195 & Reject $\mathrm{H}_{0}$ & Significant \\
\hline $\mathrm{X}_{3}$ & 0.0014 & 0.739 & Reject $\mathrm{H}_{0}$ & Significant \\
\hline $\mathrm{X}_{4}$ & 0.0000 & -0.147 & Reject $\mathrm{H}_{0}$ & Significant \\
\hline $\mathrm{X}_{5}$ & 0.0002 & 0.001995 & Reject $\mathrm{H}_{0}$ & Significant \\
\hline
\end{tabular}

The researchers made the model in log-lin form. By this model, the researchers can measure the agricultural productivity contributed by the independent variables which are GEA, ALA, EA, ARME and ECPC. The coefficients in this log-lin model (semilog model) with slope coefficient measures the constant absolute change in $\mathrm{Y}$ for a given proportional or relative change in the value of the regressor. In other words, the coefficient is the estimated percent change in the dependent variable for a unit change in the independent variables.

The final regression result with five (5) explanatory variables and 34 observations shows that Agricultural Land Area, Employment, Government Expenditure on Agriculture, Agriculture Raw Material Export, Electric Consumption per Capita are significantly related to Agricultural Gross Value Added having t-values of 3.737, $3.575,3.114,6.991$ and 4.266, respectively, which are greater than the critical t-value of 2.467 , with 28 degrees of freedom at 0.01 level of significance. Therefore, the explanatory variables such as Agricultural Land Area, Employment, Government Expenditure, Agriculture Raw Material Export, Electric Consumption per Capita have significant effect on Agriculture Gross Value Added when taken individually.

The Agricultural Land Area has a coefficient of 0.739 which shows that a million square kilometer increase in the agricultural land area would trigger 0.739 percent increase in GVA. Employment has a coefficient of 0.195 which implies that for every million person employed in agriculture would lead to 0.195 percent increase in GVA. Government Expenditure has a coefficient of 0.00000554 implies that for every million-peso increase in government expenditure on agriculture would trigger 0.00000554 percent increase in GVA. Agriculture Raw Material Export has a coefficient of -0.147 which implies that for every unit percent increase merchandise of Agriculture raw material would lead to 0.147 percent decrease in Gross Value Added. Electric Consumption per Capita has coefficient of 0.0019 which implies that in every kilo-watt-hour increase in Electric Consumption per Capita would trigger to 0.0019 percent increase in Gross Value Added.

The Chow-Breakpoint test obtained a computed F-value of 2.79 which is below the f-critical value of 3.76 at 0.01 level of significance with 6 and 22 degrees of freedom. Therefore, the model can be used for forecasting. 


\subsection{Actual Vs. Predicted}

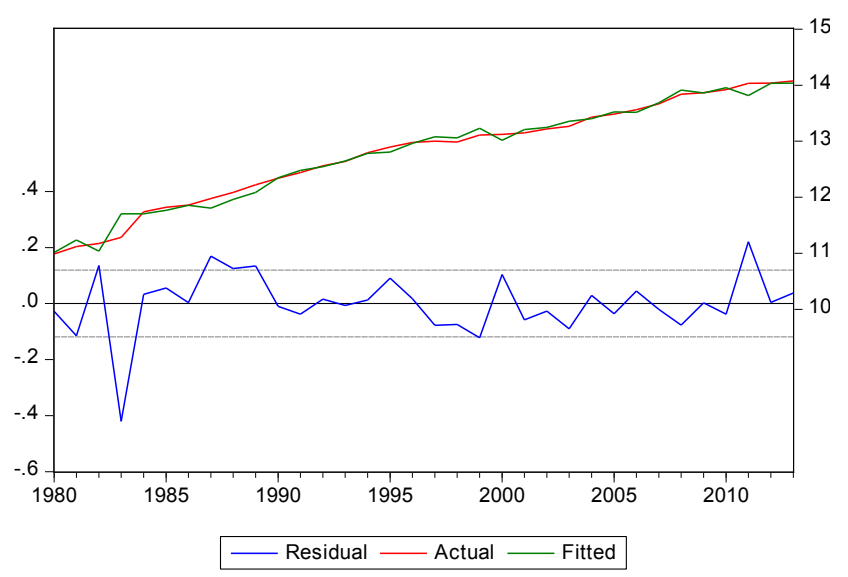

Figure 8. Actual Vs. predicted value.

Shown in Figure 9 is a scatterplot projecting the predicted values being compared to the actual values of $y$. It implies a good fit; the points are close to the fitted line. Predicted values are close to the values of actual values of $y$. Therefore, $r$-squared is high enough implying goodness of fit.

Table 3. Paired T- test result

\begin{tabular}{|l|l|l|}
\hline & p-value & Decision \\
\hline Actual - Predicted & 1.000 & Do not reject $\mathrm{H}_{0}$ \\
\hline
\end{tabular}

Shown in Table 3 is the paired test result comparing means of actual and predicted values of $y$. The $p$-value reflects 1.000 which is greater than the level of significance 0.01 . Thus, the null hypothesis that there is no statistically significant difference between the means of Actual values versus predicted holds true. In other words, the difference between the two is equal to zero. Moreover, the result shows that both groups have approximately equal variances.

\subsection{Causation}

Table 4. Pairwise granger causality tests

\begin{tabular}{|l|l|l|}
\hline Null Hypothesis: & p-value & Decision \\
\hline $\mathrm{X}_{2}$ does not Granger Cause $\mathrm{Y}$ & 0.320 & Fail to Reject Null \\
\hline Y does not Granger Cause $\mathrm{X}_{2}$ & 0.816 & Fail to Reject Null \\
\hline $\mathrm{X}_{3}$ does not Granger Cause $\mathrm{Y}$ & 0.015 & Fail to Reject Null \\
\hline $\mathrm{Y}_{\text {does not Granger Cause } \mathrm{X}_{3}}$ & 0.009 & Reject the Null \\
\hline $\mathrm{X}_{5}$ does not Granger Cause $\mathrm{Y}$ & 0.013 & Fail to Reject Null \\
\hline
\end{tabular}

\begin{tabular}{|l|l|l|}
\hline Y does not Granger Cause $\mathrm{X}_{5}$ & 0.032 & Fail to Reject Null \\
\hline $\mathrm{X}_{4}$ does not Granger Cause $\mathrm{Y}$ & 0.096 & Fail to Reject Null \\
\hline Y does not Granger Cause $\mathrm{X}_{4}$ & 0.244 & Fail to Reject Null \\
\hline $\mathrm{X}_{1}$ does not Granger Cause $\mathrm{Y}$ & 0.001 & Reject the Null \\
\hline $\mathrm{Y}$ does not Granger Cause $\mathrm{X}_{1}$ & 0.710 & Fail to Reject Null \\
\hline
\end{tabular}

As shown in Table 4, Government Expenditure does not Granger cause Real Gross Value Added and vice versa. Therefore, Government Expenditure cannot be used for forecasting the future values of Gross Value Added. Same case with Electric Consumption per capita and Real Gross Value Added; and; Agriculture Raw Material Export and Real Gross Value Added, and, vice versa. On the other hand, we fail to reject the null hypothesis stating "Employment in Agriculture does not Granger-cause Real Gross Value Added", but we do reject "Real Gross Value Added does not Granger-Cause Employment". Thus, it appears that Granger causality runs one-way from Real Gross Value Added to Employment and not the other way around. Moreover, we do reject the null hypothesis "Agriculture Land Area does not Granger Cause Real Gross Value Added", but, fail to reject "Real Gross Value Added does not Granger Cause Agriculture Land Area". Therefore, Granger causality runs one-way from Agriculture Land Area to Real Gross Value Added, and, not the other way around.

\section{Conclusions}

The $t$-values of all independent variables exceed the $t$-critical value at 0.01 level of significance. That is, the explanatory variables such as Agricultural Land Area, Employment, Government Expenditure on Agriculture, Agriculture Raw Material Export, Electric per Consumption per Capita have significant effects to Agriculture Real Gross Value Added when taken individually. Additionally, the f-statistic exceeds the F-critical value at 0.01 significance level. This implies that the explanatory variables such as Agricultural Land Area, Employment, Government Expenditure on Agriculture, Agriculture Raw Material Export, Electric per Consumption per Capita have significant effect to Agriculture Real Gross Value Added when taken collectively. The adjusted R-squared tells that 98.53 percent of the time, the Agricultural Land Area, Employment, Government Expenditure on Agriculture, Agriculture Raw Material Export, Electric per Consumption per Capita will explain the variation in 
Agriculture Real Gross Value Added. Using the Ramsey RESET, there is no specification error in the model used and can be used for policy recommendation.

Testing the Chow-Breakpoint, the parameters are stable and can be used for forecasting.

\section{References}

1. Philippine Agriculture in Figures: Overview of the Philippine Agriculture [Internet]. [cited 2017 Oct 05]. Available from: crossref.

2. Gujarati, Damodar N. Basic econometrics, Fourth Edition. The McGraw-Hill Companies; 2004.

3. Matrix Model [Internet]. [cited 2017 Jun 15]. Available from: crossref.

4. Eviews 7 Help Topics: Granger Causality [Internet]. [cited 2017 Jun 06]. Available from: crossref.

5. SPSS: Paired Sample T-Test [Internet]. [cited 2017 Jun 15]. Available from: crossref.

6. Adelman, I. Theory of economic growth and development. Oxford University Press; 1961. p. 25-40.

7. Kataria K, Curtis J, Balman A. Drivers of agricultural physical capital development theoretical framework and hypotheses. Comparative Analysis of Factor Markets for Agriculture across the Member States; 2012. p. 8, 18.

8. Lambert DM, Cho S. Forecasting input demand shocks on China's gross value of agricultural output. The Review of Regional Studies. 2008; 38(3):343-59.

9. Rajeb M, Hossain MM, Chakraborty L. Gross value added of agriculture sector in Bangladesh: An econometric investigation. Terengganu International Business and Economics Conference (TIBEC II); 2010. p. 364-77.

10. Tripathi, A. Total factor productivity growth in Indian agriculture. Journal of Global Economy. 2008; 6(4):286-98.

11. Echevarria, C. A three-factor agricultural production function: The case of Canada (Thesis, University of Saskatchewan); 1998.

12. Elias VJ. Government expenditures on agriculture in Latin America; 1981.

13. Sanguyo EB, Dalag RM. Impacts of selected government investment expenditures on agricultural productivity and output. Bureau of Agricultural Statistics, Agricultural Accounts and Statistical Indicators Division (AASID); 2005. p. 1-28

14. Evenson RE, Sardido ML. Regional total factor productivity changes in Philippine agriculture. Journal of Philippine Development. 1986; 13(23):40-61.
15. Llanto GM. The impact of infrastructure on agricultural productivity [Internet]. 2012. Available from: crossref.

16. Briones RM. The Philippines country environmental analysis: Land degradation and rehabilitation in the Philippines; 2009. p. 9-15.

17. Cooper R, John AA. Theory and Application of Macroeconomics v.1.0; 2012. Chapter 16, p. 813-15.

18. Chang H, Zepeda L. Agricultural productivity for sustainable food security in Asia and Pacific: The role of investment. Agricultural investment and productivity in developing countries. Rome: Food and Agriculture Organization of the United Nations; 2001. p. 75-89.

19. Zepeda L. Agricultural Investment and Productivity in Developing Countries. Rome: Food and Agriculture Organization of the United Nations; 2001.

20. Ebere C, Osundina KC. Government expenditure on agriculture and economic growth in Nigeria. International Journal of Science and Research. 2014; 3(9):188-94.

21. Briones NM. Environmental sustainability issues in Philippine agriculture. Asian Journal of Agriculture and Development. 2005; 2(1,2):67-77.

22. Briones RM. Agriculture, rural employment, and inclusive growth. PIDS Discussion Paper Series. 2013; 2013-39:1-34.

23. Briones RM. Impact assessment of the agricultural production support services of the Department of Agriculture (DA) on the income of poor farmers/Fisherfolk: Review of the Evidence. PIDS Discussion Paper Series. 2013; 2013-23:1-37.

24. Philippine Agriculture: Status, Trends and Challenges. DOST-PCARRD [Internet]. [cited 2017 May 05]. Available from: crossref.

25. Philippines. National Economic and Development Authority, issuing body. Philippine development plan, 2011-2016: Results Matrices. Chapter 4: Competitive and Sustainable Agriculture and Fisheries Sector; 2011. p. 102-20.

26. Bruinsma J. The Resource Outlook To 2050: By How Much Do Land, Water And Crop Yields Need To Increase By 2050?. Food and Agriculture Organization of the United Nations Economic and Social Development Department; 2009.

27. Habito CF, Briones RM. Philippine Agriculture over the Years: Performance, Policies and Pitfalls [Internet]. Available from: crossref.

28. Pamplona PP. Philippine Agriculture and the High Incidence of Poverty and Unemployment. Philippine Palm Oil Development Council, Inc. [Internet]. 2012. Available from: crossref.

29. Agriculture sector grows by $2.9 \%$ in 2012 . Sun Star Manila [Internet]. [cited 2017 May 15]. Available from: crossref. 